\title{
"Elephant's Foot," a Basal Stem Disorder in Greenhouse-Grown Bell Peppers ${ }^{1}$
}

\section{Elio Jovicich and Daniel J. Cantliffe ${ }^{2}$}

Under certain conditions, vegetable greenhouse crops can develop physiological disorders that predispose plants to diseases that decrease plant growth, fruit yield, and fruit quality. One plant disorder in bell pepper (Capsicum annuum L.) is the "Elephant's Foot," which is characterized by the presence of epidermal injuries on a swollen stem region developed at the base of the plant stem (Fig. 1).

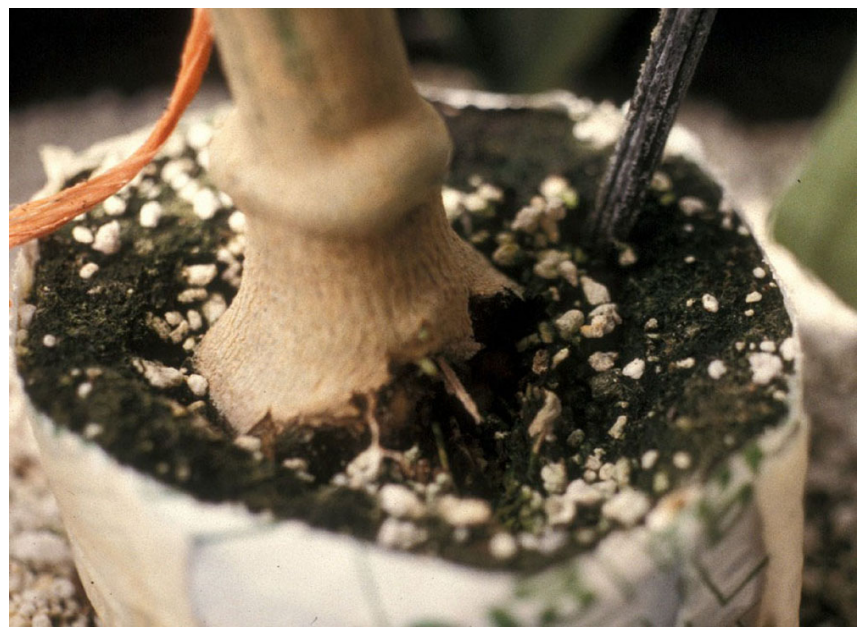

Figure 1. "Elephant's Foot" disorder in a bell pepper plant. Credits: Elio Jovicich, University of Florida.

The epidermal injuries increase the plant susceptibility to fungal infections that can lead to plant death. This publication describes the symptoms and possible causes of this basal stem physiological disorder in greenhouse-grown bell pepper, and presents pepper production methods to avoid the disorder.

\section{Bell Pepper Growing Systems in Florida Greenhouses}

In Florida, red, orange, or yellow bell pepper fruits produced in greenhouses are harvested from plants grown in soilless culture. The plants are grown in containers such as flat polyethylene bags or nursery pots filled with media such as perlite, pine bark, or peat mixes (Fig. 2), or in rockwool slabs. The media can be reused for two or three crops if contamination by a pathogen is not apparent. Pepper plants in soilless culture are frequently irrigated (from 1 to 30 times per day) with a complete nutrient solution delivered through drip irrigation. Depending mainly on the plant growth stage, environmental conditions, and type of media, a greenhouse-grown pepper plant can receive from $13 \mathrm{fl} \mathrm{oz}$ up to $1.5 \mathrm{gal}$ of nutrient solution per day $(385 \mathrm{~mL}$ to $5.7 \mathrm{~L}$ per plant per day). The concentrations of the nutrients required by pepper plants are increased with plant growth. The $\mathrm{pH}$ of the irrigation solution is maintained at values

1. This document is HS959, one of a series of the Horticultural Sciences Department, Florida Cooperative Extension Service, Institute of Food and Agricultural Sciences, University of Florida. Publication date: January 2004. Please visit the EDIS Web site at http://edis.ifas.ufl.edu.

2. Elio Jovicich, graduate student, Daniel J. Cantliffe, professor and chair, Horticultural Sciences Department, Cooperative Extension Service, Institute of Food and Agricultural Sciences, University of Florida, Gainesville, 32611.

The Institute of Food and Agricultural Sciences is an equal opportunity/affirmative action employer authorized to provide research, educational information and other services only to individuals and institutions that function without regard to race, color, sex, age, handicap, or national origin. For information on obtaining other extension publications, contact your county Cooperative Extension Service office. Florida Cooperative Extension Service/Institute of Food and Agricultural Sciences/University of Florida/Christine Taylor Waddill, Dean. 


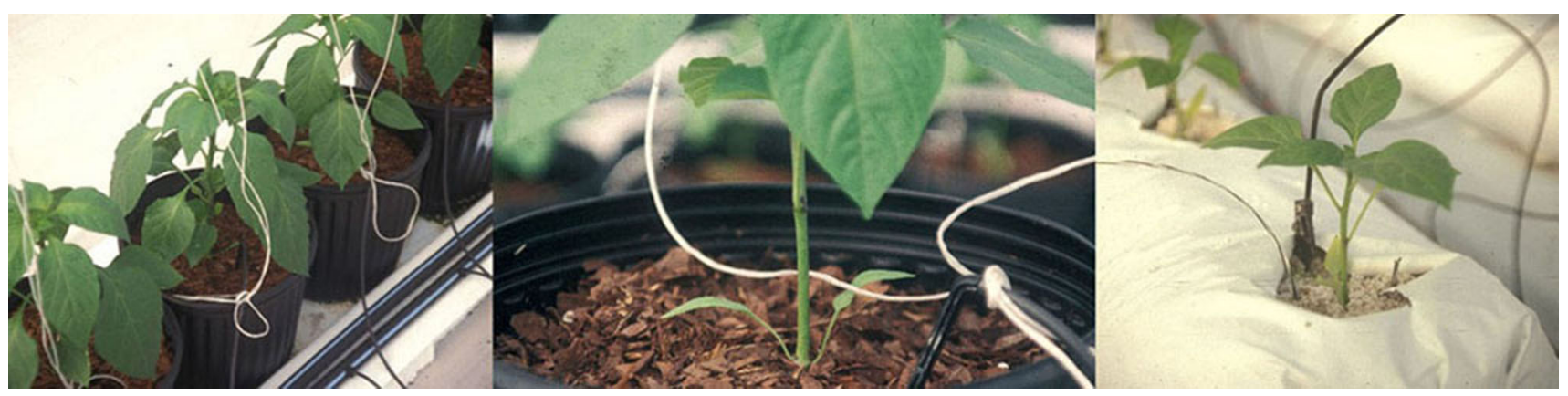

Figure 2. Pepper plants transplanted into pots with pine bark (left and center) and into flat bags filled with perlite (right). Credits: Elio Jovicich, University of Florida

between 5.5 and 6.5 , and the electrical conductivity (EC), depending on the nutrient concentration levels, have values between 1.5 and $2.5 \mathrm{mS} / \mathrm{cm}$.

With the use of soilless media, soilborne diseases are minimal; however, certain management practices (i.e., irrigation, fertilization, transplant depth, and position of the irrigation emitters) can lead to localized plant injuries, sites where opportunistic fungi can invade, and interference with the plants normal water and nutrient uptake.

\section{Symptoms of the "Elephant's Foot" Disorder}

Greenhouse-grown pepper plants from various areas of the world, may exhibit symptoms where the base of the main stem becomes swollen below the cotyledonary node level and crack-like wounds develop at the base of the stem's epidermis (Fig. 3). In all situations where the disorder was noticed, (peppers grown in soilless media in the greenhouse and in one experimental crop where plants in soilless media were grown outdoors), the basal stem injuries were visible in the epidermal tissues below the cotyledonary nodes (root/shoot junction, the hypocotyl in the seedling) and, particularly, in plants with the cotyledonary node located above the surface of the media. In Florida, these symptoms have been observed 40 or more days after transplanting (in fall and spring crops), in plants in which the first green fruits were at least 1 inch in diameter (Jovicich et al., 1999). Symptoms have been seen from just a few plants to up to $70 \%$ of the plants in the greenhouse. Because of the appearance of the basal plant stem, the disorder has received names such as "Elephant's Foot" and "Foot Corkiness."
The "Elephant's Foot" disorder is important because it increases the susceptibility of the plant to invasion of opportunist vascular-wilt fungi such as Fusarium oxysporum, which can enter the basal stem tissues through epidermal wounds and develop a localized rot (Fig. 4).

At early stages of a basal stem rot, browning of internal vessels is evident when the basal stem is sectioned lengthwise in plants that present temporary wilts (especially during afternoon hours) (Fig. 5). Plants that present temporary wilts have localized lesions at the basal stem region only, but the root system is white and fibrous (Fig. 6), characteristic of those healthy soilless-grown pepper plants.

Temporary plant wilt may be followed by a sudden plant wilt and plant death (Fig. 7). Wilted plants may appear randomly throughout the crop, or they may be observed in plants at the end of the rows. Not all the plants with "Elephant's Foot" disorder will wilt, but those which develop a basal stem rot generally do not recover from wilting. If they do recover, fruit yield is greatly reduced.

\section{Causes of "Elephant's Foot" Disorder}

Peppers are relatively sensitive to moderate and high levels of salts in the growing media solution. Symptoms of basal stem epidermal injuries have been observed in both soil and soilless cultivated bell pepper plants where excessive amount of salts (salts from the soil, irrigation water, or fertilizers) concentrated around the base of the stem (Fig. 8). Epidermal injuries on the base of the stem can be a plant response to salt accumulation and excess of humidity (Jovicich and Cantliffe, 2004). Deposits of 


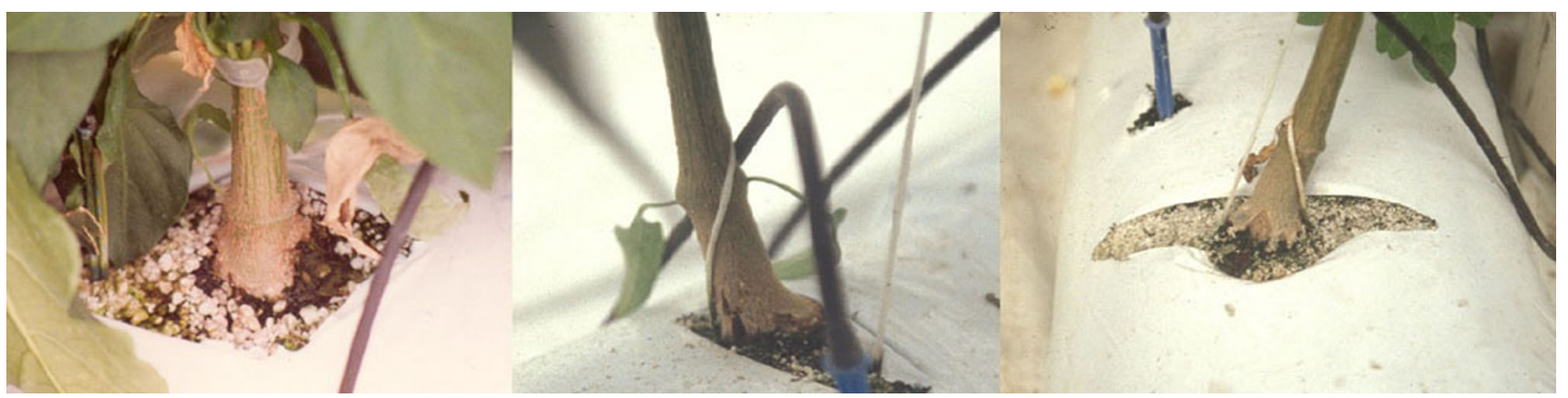

Figure 3. "Elephant's Foot" disorder in pepper plants transplanted with the cotyledonary node above the surface of the media. Credits: Elio Jovicich, University of Florida

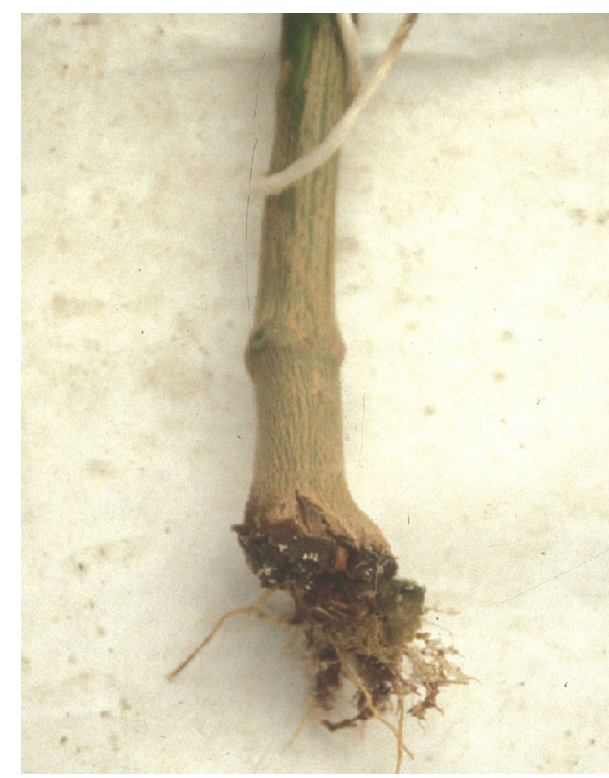

Figure 4. Pepper plant with "Elephant's Foot" disorder symptoms which has already developed a basal stem rot. Crack-like epidermal wounds are present on the root/stem junction (hypocotyl in the seedling). The plant was almost completely wilted and it easily separated from the roots when it was pulled out of the container. Credits: Elio Jovicich, University of Florida.

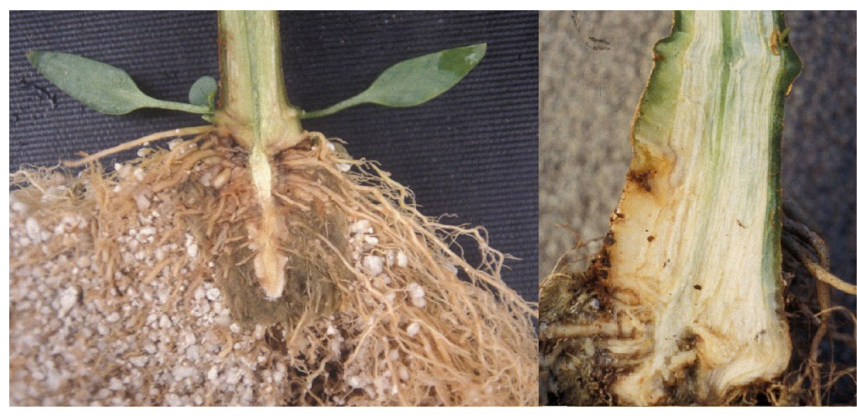

Figure 5. Early stages of basal stem rot in pepper plants with "Elephant's Foot" symptoms. Brown discoloration and rot in the crown of the roots and in the cortex. Credits: Elio Jovicich, University of Florida.

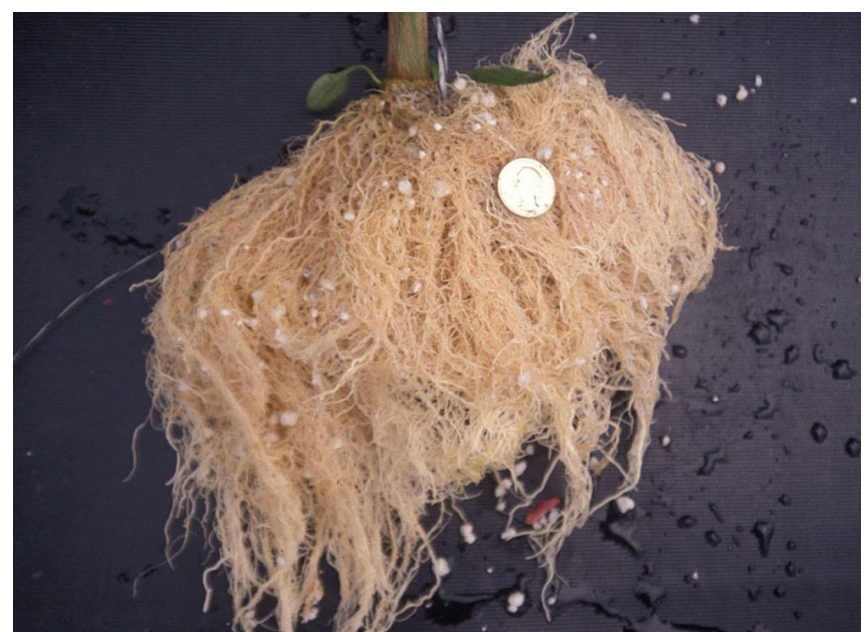

Figure 6. Healthy root system of a bell pepper plant (grown in a bag with perlite) that started with symptoms of plant wilt during afternoon hours. Credits: Elio Jovicich, University of Florida.

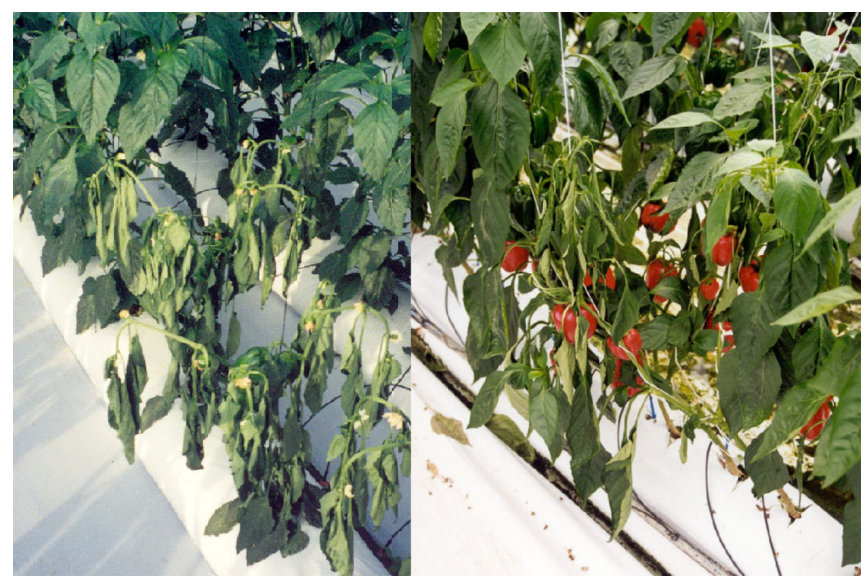

Figure 7. Sudden wilts of bell pepper plants with "Elephant's Foot" disorder that ended in a basal stem rot. Credits: Elio Jovicich (I) and Elizabeth Lamb (r), University of Florida

salts on basal stem epidermal tissues can contribute to localized injuries, which predispose the plant to an infection by opportunistic pathogens. The level of 


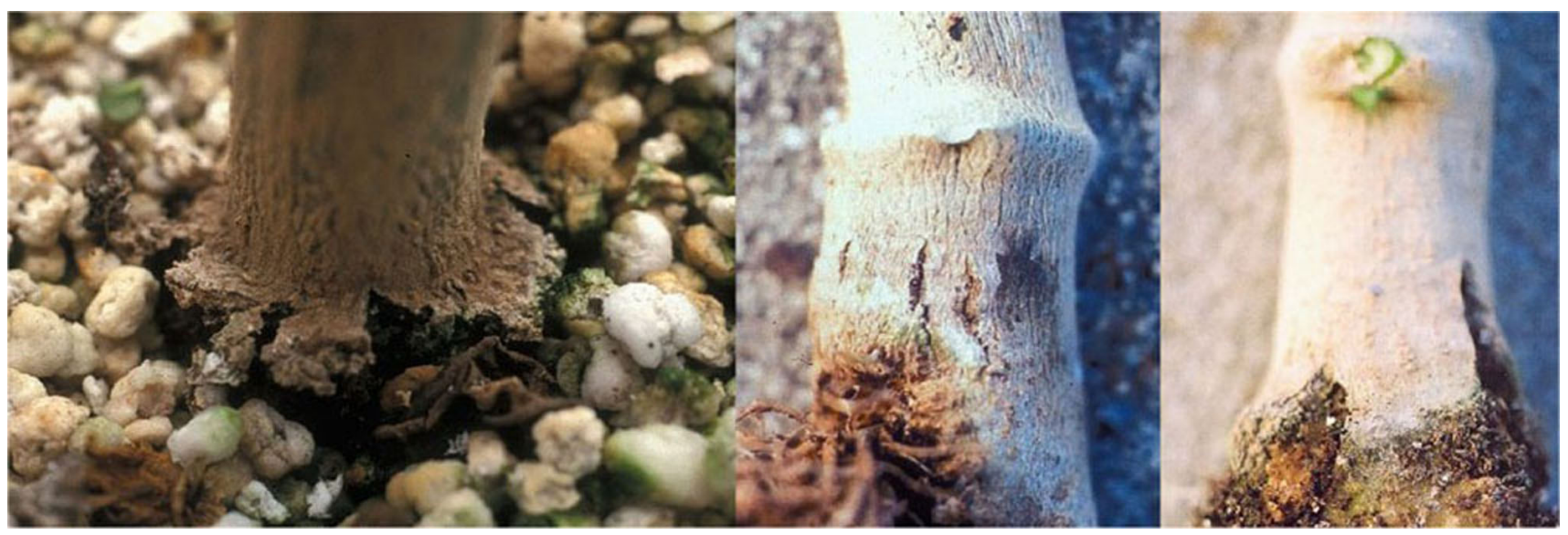

Figure 8. Epidermal injuries are more common when salts accumulate at the base of the stem at the media/stem interface (notice salt deposits near the epidermal wounds). Credits: Elio Jovicich, University of Florida

salts deposited around the base of the stem depend on the volume and concentration of nutrient solution applied and on the placement of the emitter with respect to the transplant, as salts usually concentrate on the wet and dry boundary area of the soilless media.

Epidermal injuries are more likely to occur in plants where seedlings were transplanted with the cotyledonary node above the soilless media surface than in plants where the seedlings were transplanted to the depth of the first true leaves. The stem/root junction might be more sensitive to salts than upper regions of the stem. In an experiment where pepper plants were grown in 3-gallon (11-L) pots with perlite, peat mix, coconut coir, or pinebark, the type of media did not appear to have an effect on the salt accumulation nor on the appearance of epidermal wounds.

All factors which may be conducive to the basal stem disorder are not known, although plants under the following production management practices were more likely to develop basal stem epidermal injuries:

- Plants with frequent irrigation events with nutrient solutions delivered close to the basal stem, leading to increased salt deposits at the stem base.

- Plants with insufficient water supply, where salts concentrate in the media solution and in the top layers of the containerized media.
- Plants located at the end of the rows, where evapotranspiration is greater, and where salts accumulate in greater amounts at the top of the soilless media.

- Full-grown plants with the irrigation emitter delivering nutrient solution very close to the stem base (1 inch or less), creating increased salt deposits on the stem base.

- High concentration of salts can occur in plants where seedlings were transplanted with the rootballs in rockwool cubes or open-bottom transplant containers, and which were placed directly over the soilless media of the nursery pot or flat bag, and in which the irrigation emitters were located at the bottom (or at the top) of the cubes or containers (Fig. 9). This transplant practice is not commonly used in Florida. The saline environment around the base of the stem can be kept low by transplanting the rootball directly into the pot media instead of using a plant container or rockwool cube buried shallowly into the growing media.

\section{Saving Pepper Plants from Wilting Once Symptoms of the "Elephant's Foot” Disorder Were Noticed}

Plants with temporary wilting due to an early basal stem rot have limited water and nutrient uptake which leads to reduced fruit yields. Recovery of pepper plants from temporary wilting is difficult, although partial recovery may be possible by 


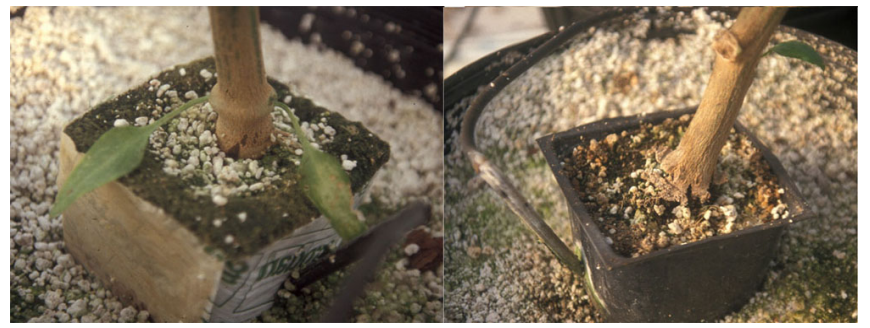

Figure 9. Pepper plants in open-bottom containers placed directly over the media or shallowly buried into the pot media at transplanting. These plants developed epidermal injuries at the base of the stem. Credits: Elio Jovicich, University of Florida

reducing the amount of water and moving the irrigation emitter further from the base of the stem. However, a drastic reduction of water and nutrients due to change in irrigation practices and the existence of already damaged basal stem vessels, can lead to the development of blossom-end rot in developing pepper fruits.

\section{Prevention of "Elephant's Foot" Disorder}

Prevention of the development of epidermal injuries at base of the stems, especially in the regions below the cotyledonary node (where pepper plants seem to be most sensitive to high concentration of salts) is a way of avoiding a subsequent basal stem rot. The following management practices have shown to reduce the incidence of "Elephant's Foot" disorder:

- Transplanting seedlings directly into the bag or pot media, with the cotyledonary node below the surface of the media (to the depth of the first true leaves) has avoided symptoms of swelling and epidermal injuries at the cotyledonary node and at the stem media-air interface (Fig. 10) without any subsequent problems associated with plant growth or fruit production.

- Moving back the irrigation emitters (stakes), gradually from 1 inch near the seedling to 2 or 3 inches from the base of the stem during the first 3 weeks after transplanting, helped to keep the base of the stem dry and avoided epidermal injuries and basal stem rot (Fig. 11).

- Presently there is little information about pepper cultivars that are more or less prone to develop the "Elephant's Foot" disorder. A bell pepper cultivar, HA3378 (Hazera Seeds Ltd.), was more susceptible to developing this basal stem disorder than Kelvin and Cubico (De Ruiter Seeds Inc.).

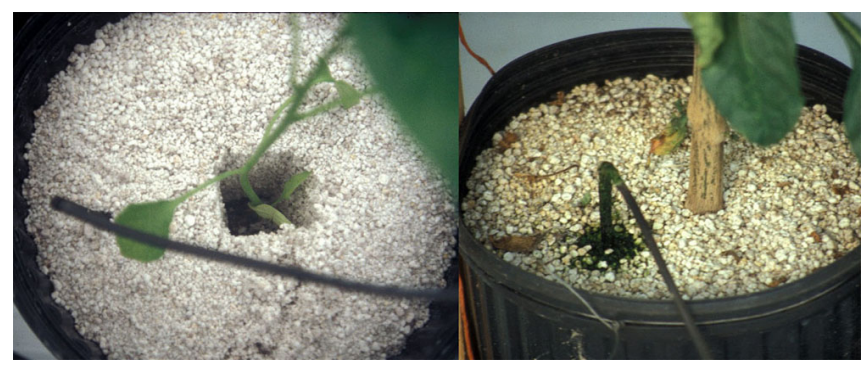

Figure 10. Transplanting seedlings to the depth of the first true leaves (left) prevented the appearance of "Elephant's foot" disorder (right). Credits:

Elio Jovicich, University of Florida

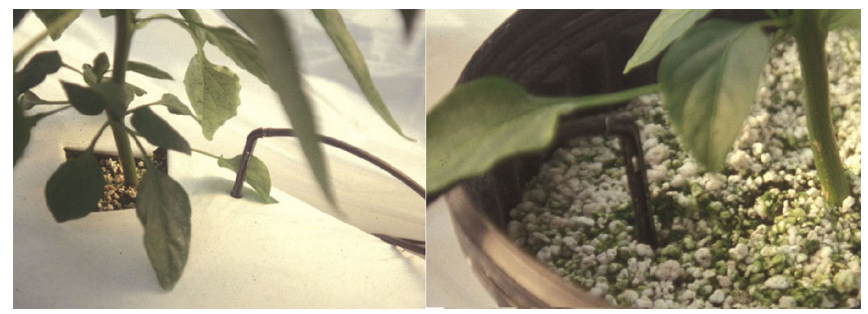

Figure 11. In pepper plants grown in pots or in bags, irrigation stakes are gradually moved back from the stem after transplanting. Credits: Elio Jovicich, University of Florida

\section{Other Causes that Lead to Similar Symptoms of "Elephant's Foot" Disorder}

\section{- Temporary plant wilting due to insufficient} water in the media. Pepper plants receiving low amounts of nutrient solution may show temporary wilt during warm afternoon hours. As a general guide, check for the volume of solution drained at the bottom of plant containers. One should collect about $10 \%$ (small plants or cool weather) to $30 \%$ (large plants or warm weather) of the total volume delivered to the plants at the end of a day. In addition, periodically monitor the solution drainage throughout the day, to find if plants are getting enough water during afternoon hours. High EC values in the delivered nutrient solution and in the solution within the media can damage the root system making it susceptible to fungal infection. 
- Plant wilting and basal stem rot due to excessive water in the media. Plant wilt and basal stem rot occur in situations of excessive irrigation of a medium with high water holding capacity or, under water logging (containers with no drainage holes or roots obstructing the drainage holes) both which can deprive the root zone from necessary oxygen concentrations and lead to root death and thus promote fungal infections.

- Plant wilting, swelling of the base of the stem, and basal stem rot caused by insect damage. Fungus gnats (Bradysia spp.) larvae feed on roots of soilless-grown pepper plants. The damaged roots can develop fungal infections that lead to plant wilts (Fig. 12). Search for the presence of 1) adult flies near the base of the plant stem and on algae growing in the drainage system and 2) larvae on the base of the stem and upper root region of wilted plants (use a knife to make longitudinal sections of the basal stem to find the larvae). Avoid water ponds and stagnant drainage water where algae can develop and where fungus gnats can complete part of their life cycle. There are effective biological methods for controlling fungus gnats (i.e., Bacillus thuringensis, predatory mites, and predatory nematodes). For control of fungus gnats, see Management of Fungus Gnats in Ornamentals at http://edis.ifas.ufl.edu/IG125.

- Plant wilting caused by pathogens. Pepper plant wilting can be caused by pathogens that eventually infect the plant, or contaminated the soilless media, and/or the nutrient solution in open or closed irrigation systems. In pepper, lateral roots can develop below the cotyledonary node, even when located above the media surface. Natural openings created by newly emerging lateral roots are additional sites of entry for certain fungi. Air-exposed lateral roots can also be damaged by fungus gnats larvae.

Wilting and basal stem rot in soilless-grown pepper plants can be a plant response to many different factors. It is recommended that growers contact their County Extension agent and that samples of affected and healthy plants be sent to The
Florida Extension Plant Disease Clinic to obtain a diagnosis and to check for other possible pathogenic fungal or bacterial diseases, or insect damage. For instructions about how to collect and send a plant material sample for disease diagnostic to the Florida Extension Plant Disease Clinic, read Florida Extension Plant Disease Clinic Network at http://edis.ifas.ufl.edu/SR007.

\section{References}

Jovicich, E., D.J. Cantliffe, and G.J. Hochmuth. 1999. "Elephant's Foot," a Plant Disorder in Hydroponic Greenhouse Sweet Pepper. Proc. Fla. Soc. Hort. Sci. 112:310-312.

Jovicich, E. and D.J. Cantliffe. 2004. Salts Deposited on the Lower Stem of Bell Pepper Contribute to a Basal Stem Disorder in Soilless, Greenhouse-grown Plants. HortScience 39(1) (in press).

\section{Additional Information}

For more information on greenhouse production of bell pepper and other vegetable crops, please visit the Protected Agriculture Project web site, http://www.hos.ufl.edu/protectedag/ .

Fusarium Crown and Root Rot of Tomato in Florida (which affects field and greenhouse crops and can also affect pepper).

http://plantpath.ifas.ufl.edu/takextpub/FactSheets/ sp184.pdf

Fusarium Stem and Fruit Rot of Greenhouse Pepper (Fusarium solani may also infect plants through the base of the stems of salt-stressed plants). http://www.gov.on.ca/OMAFRA/english/crops/facts/ 01-083.htm

Fusarium Stem Rot of Greenhouse Pepper (Fusarium solani reported in Florida greenhouse-grown peppers). http://edis.ifas.ufl.edu/CV276

Management of Fungus Gnats in Ornamentals (Refer to authors for management in greenhouse vegetable crops). http://edis.ifas.ufl.edu/IG125 


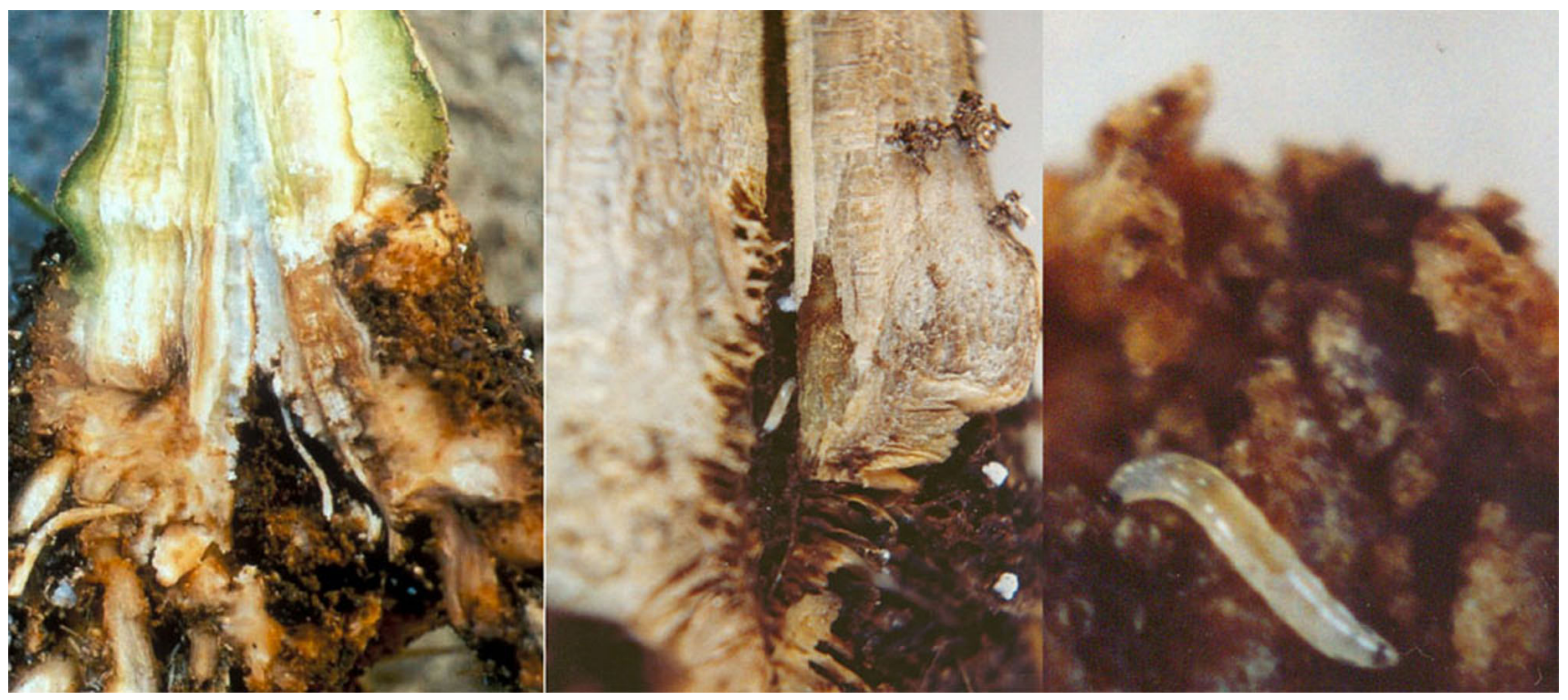

Figure 12. Longitudinal section of a pepper with basal stem rot (left) that developed after damage by fungus gnat larvae (center and right). Credits: Elio Jovicich, University of Florida

Irrigation of Greenhouse Vegetables - Florida Greenhouse Vegetable Production Handbook, Vol 3. http://edis.ifas.ufl.edu/CV264

Fertilizer Management for Greenhouse Vegetables - Florida Greenhouse Vegetable Production Handbook, Vol 3. http://edis.ifas.ufl.edu/CV265 